\title{
MASTER
}

\section{Sulfur Hexafluoride Purification from Mixtures With Air: A Process Feasibility Study}

Joseph J. Perona
J. S. Watson 


\section{DISCLAIMER}

This report was prepared as an account of work sponsored by an agency of the United States Government. Neither the United States Government nor any agency Thereof, nor any of their employees, makes any warranty, express or implied, or assumes any legal liability or responsibility for the accuracy, completeness, or usefulness of any information, apparatus, product, or process disclosed, or represents that its use would not infringe privately owned rights. Reference herein to any specific commercial product, process, or service by trade name, trademark, manufacturer, or otherwise does not necessarily constitute or imply its endorsement, recommendation, or favoring by the United States Government or any agency thereof. The views and opinions of authors expressed herein do not necessarily state or reflect those of the United States Government or any agency thereof. 


\section{DISCLAIMER}

Portions of this document may be illegible in electronic image products. Images are produced from the best available original document. 
Printed in the United States of America. Available from National Technical Information Service

U.S. Department of Commerce

5285 Port Royal Road, Springfield, Virginia 22161

NTIS price codes-Printed Copy: A03; Microfiche A01

This report was prepared as an account of work sponsored by an agency of the United States Government. Neither the United States nor any agency thereof, nor any of their employees, makes any warranty, expressed or implied, or assumes any legai liability or responsibility for any third party's use or the results of such use of arly information, apparalus, pruducl ur prucess disclused in llis repuil, ur represents that its use by such third party would not infringe privately owned rights. 


\section{MASTER}

ORNL/TM-6939

Contract No. W-7405-eng-26

CHEMICAL TECHNOLOGY. DIVISION

SULFUR HEXAFLUORIDE PURIFICATION FROM MIXTURES

WITH AIR: A PROCESS FEASIBILITY STUDY

Joseph J. Perona
J. S. Watson

Date Published - October 1979

NOTICE This document contains information of a preliminary nature. It is subject ro revlsion or correction and therefore does not represent a final report.

\footnotetext{
OAK RIDGE NATIONAL LABORATORY

Oak Ridge, Tennessee 37830

operated by

UNION CARBIDE CORPORATION

for the

DEPARTMENT OF ENERGY
} 
THIS PAGE

WAS INTENTIONALLY

LEFT BLANK 
CONTENTS

Page

ABSTRACT . . . . . . . . . . . . . . . . . . 1

1. INTRODUCTION ....................... 1

2. SELECTION OF BASE CASES. . . . . . . . . . . . . 3

3. PROPERTIES OF SULFUR HEXAFLUORIDE. . . . . . . . . . . 3

4. AIR SOLUBILITY MEASUREMENT . . . . . . . . . . . . . . . 9

5. PURIFICATION METHODS . . . . . . . . . . . . . . 11

5.1 Liquefaction. . . . . . . . . . . . . . . . 11

5.2 Molecular Sieves. . . . . . . . . . . . . . 12

5.3 Desublimation . . . . . . . . . . . . . 15

5.4 Adsorption onto Activated Carbon. . . . . . . . . . . 21

6. ACKNOWLEDGMENTS. . . . . . . . . . . . . . . 27

7. REFERENCES .... . . . . . . . . ....... 27 


\section{SULFUR HEXAFLUORIDE PURIFICATION FROM MIXTURES}

WITH AIR: A PROCESS FEASIBILITY STUDY

Joseph J. Perona

J. S. Watson

\section{ABSTRACT}

Studies were made of the purification of $\mathrm{SF}_{6}$ vapor contaminated with air for application at the Holifield HeavyIon Research Facility. Liquefaction appears to be a good method for recovering about $90 \%$ of the $\mathrm{SF}_{6}$ if it is badly contaminated (15\% air), and an even greater fraction can be recovered from mixtures containing less air.

In cases where liquefaction is insufficient by itself, adsorption of $\mathrm{SF}_{6}$ on activated carbon at $-50^{\circ} \mathrm{F}$ is promising. Two carbon beds, each containing about $500 \mathrm{lb}$ of carbon, should be sufficient. The refrigeration system for 1 iquefaction and adsorption would have a capacity of about 2 tons.

As an alternative, the use of molecular sieves to trap out the air was investigated, but such a bed would require at least 15,000 lb of molecular sieves and very long cycle times. A large-scale desublimer was also investigated and appears workable, but it would require some development effort before the design could proceed with confidence.

\section{INTRODUCTION}

The Holifield Heavy-Ion Research Facility, ${ }^{1}$ now under construction at Oak Ridge National Laboratory, will use $\mathrm{SF}_{6}$ as an insulating gas.

The accelerator is contained in a pressure vessel filled with approximately 240,000 lb of $\mathrm{SF}_{6}$ gas at a pressure of about $100 \mathrm{psia}$. When entry into the pressure vessel is necessary, the $S_{6}$ must be transferred to storage. The $\mathrm{SF}_{6}$ will be stored as a liquid at ambient temperature in three $2000-\mathrm{ft}^{3}$ tanks at about 350 psia. 
The accelerator vessel will be evacuated before it is filled with $\mathrm{SF}_{6}$ from liquid storage, but it cannot be evacuated completely. Therefore, the concentration of air in the $\mathrm{SF}_{6}$ will gradually rise as the $\mathrm{SF}_{6}$ is transferred back and forth, and the $\mathrm{SF}_{6}$ will eventually require purification. Errors in operating procedures could also bring about contamination of the $\mathrm{SF}_{6}$ with air. It is virtually certain that a purification process for the $\mathrm{SF}_{6}$ will be needed during the many years of operation projected for the accelerator. This need arises not from a deterioration of insulating properties, but rather from the necessity of 1 iquefaction at ambient temperature for storage.

Purification of $\mathrm{SF}_{6}$ has been carried out on a small scale at other accelerator laboratories. At Chalk River, the $\mathrm{SF}_{6}$ has been separated from air by freezing it out with liquid nitrogen. ${ }^{2}$ The use of an activated charcoal adsorption column for purification from air and helium was described by Brassard ${ }^{3}$ in which the contaminated gas was introduced to the column in short bursts and the column was operated as a chromatograph. With the column at $-20^{\circ} \mathrm{C}\left(-4^{\circ} \mathrm{F}\right)$, a $650-\mathrm{g}$ burst of gas was admitted and the effluent for the following 1 min was vented as primarily contaminant gases. The $\mathrm{SF}_{6}$ was then collected for the next 15- to 20-min period. The column was $8 \mathrm{in}$. in diam by $33 \mathrm{in.}$ long and had a production rate of $100 \mathrm{lb} /$ day. Other studies of air adsorption into Linde $5 \mathrm{~A}$ molecular sieves have also been reported. ${ }^{4}$ Use of these methods was investigated for application to the present system. 


\section{SELECTION OF BASE CASES}

The following incident is considered as a worst case: $\mathrm{SF}_{6}$ is pumped from liquid storage into the accelerator without prior evacuation of the accelerator. The accelerator filling is stopped at the normal operating pressure of 85 psig, but it now contains 1-atm partial pressure of air. The composition of the accelerator tank is $2071 \mathrm{~b}$-moles of air and 1200 lb-moles of $\mathrm{SF}_{6}$, giving 0.15 m.f. of air.

This incident badly contaminates most of the $\mathrm{SF}_{6}$ inventory and therefore serves as a "worst" case. The purification process must be capable of restoring the $\mathrm{SF}_{6}$ inventory to a purity of about $99 \%$ in a period of 2 to 3 weeks. It should also be capable of routinely purifying a small recycle stream containing approximately $1 \%$ air. These two cases are denoted as Case 1, the worst case, and Case 2, the routine purification of slightly contaminated $\mathrm{SF}_{6}$.

\section{PROPERTIES OF SULFUR HEXAFLUORIDE}

Many important thermodynamic and transport properties of $\mathrm{SF}_{6}$ were presented by Milner ${ }^{5}$ and by a vendor booklet from Allied Chemical Co. Only those properties required for understanding the process descriptions that follow are reported here.

The vapor pressure is of paramount importance in considering vaporization and condensation processes (Table 1). Notice that at the melting point, $-59.4^{\circ} \mathrm{F}\left(-50.7^{\circ} \mathrm{C}\right)$, the vapor pressure is above atmospheric. The sublimation temperature is $-83^{\circ} \mathrm{F}\left(-63.8^{\circ} \mathrm{C}\right)$. 
Table 1. Vapor pressure and density of $\mathrm{SF}_{6}$

\begin{tabular}{lcccc}
\hline \multicolumn{2}{c}{ Temperature } & $\begin{array}{c}\text { Vapor pressure } \\
\text { (psig) }\end{array}$ & $\begin{array}{c}\text { Liquid density } \\
\left(1 \mathrm{~b} / \mathrm{ft}^{3}\right)\end{array}$ & $\begin{array}{c}\text { Vapor density } \\
\left(1 \mathrm{~b} / \mathrm{ft}^{3}\right)\end{array}$ \\
\hline${ }^{\circ} \mathrm{F}$ & ${ }^{\circ} \mathrm{C}$ & & & \\
-83 & -63.8 & 0 & & \\
-59.4 (mp) & -50.7 & 17.8 & 115.384 & 1.251110 \\
-58.00 & -50.0 & 19.1367 & 113.665 & 1.541793 \\
-48.00 & -44.4 & 27.5522 & 117.890 & 1.885678 \\
-38.00 & -38.8 & 38.4335 & 110.052 & 2.290409 \\
-28.00 & -33.3 & 49.1701 & 108.145 & 2.764523 \\
-18.00 & -27.7 & 62.8074 & 106.160 & 3.318272 \\
-8.00 & -22.2 & 78.5951 & 104.510 & 3.825729 \\
0.0 & -17.8 & 92.9393 & 102.359 & 4.552402 \\
10.0 & -12.2 & 113.0773 & 100.097 & 5.395822 \\
20.0 & -6.7 & 135.9532 & 97.703 & 6.376521 \\
30.0 & -1.1 & 161.7704 & 95.153 & 7.519135 \\
40.0 & 4.4 & 190.7345 & 92.411 & 8.856692 \\
50.0 & 10.0 & 222.9780 & 89.428 & 10.439324 \\
60.0 & 15.5 & 258.8184 & 86.126 & 12.336124 \\
70.0 & 21.1 & 298.4354 & 82.376 & 14.668706 \\
80.0 & 26.7 & 342.2993 & 77.938 & 17.656662 \\
90.0 & 32.2 & 390.7000 & 72.237 & 21.823471 \\
100.0 & 37.8 & 444.3533 & 62.905 & 29.147339 \\
110.0 & 43.3 & 504.4993 & 45.260 & 36.398193 \\
114.15 & 45.6 & 531.8936 & & \\
\hline
\end{tabular}


Although the solubilities of oxygen and nitrogen in liquid $\mathrm{SF}_{6}$ are important, no published data on solubilities were found; therefore, solubilities were estimated using the regular solution theory described in ref. 6 . The relationship takes the form

$$
-\ln x_{i}=\ln \frac{\lambda_{1}}{y_{i}^{P}}+\lambda_{2}
$$

where

$$
\begin{aligned}
x_{i}= & \text { equilibrium solubility of gas } i, m . f . ; \\
y_{i} P= & \text { partial pressure of gas } i, \text { atm; and } \\
\lambda_{1}, \lambda_{2}= & \text { constants that depend on gas and liquid properties } \\
& \text { and temperature. }
\end{aligned}
$$

Calculated values for $\lambda_{1}$ and $\lambda_{2}$ for oxygen and nitrogen in liquid $\mathrm{SF}_{6}$ are plotted in Figs. 1 and 2. If temperature and total pressure are chosen, the gas-phase composition is fixed by the vapor pressure of $\mathrm{SF}_{6}$ and the ratio of oxygen and nitrogen in air. By choosing a range of pressures for several temperatures of interest, the solubilities shown in Fig. 3 were calculated. In these calculations, the oxygen and nitrogen in the gas phase were assumed to be present in the normal proportions found in air.

As the total pressure decreases to approach the vapor pressure of $\mathrm{SF}_{6}$, the partial pressure of air and the solubility must approach zero. Hence the solubility curve for $-50^{\circ} \mathrm{F}$ approaches an asymptote of $40 \mathrm{psia}$ as the solubility becomes very small. 
ORNL DWG 79-293

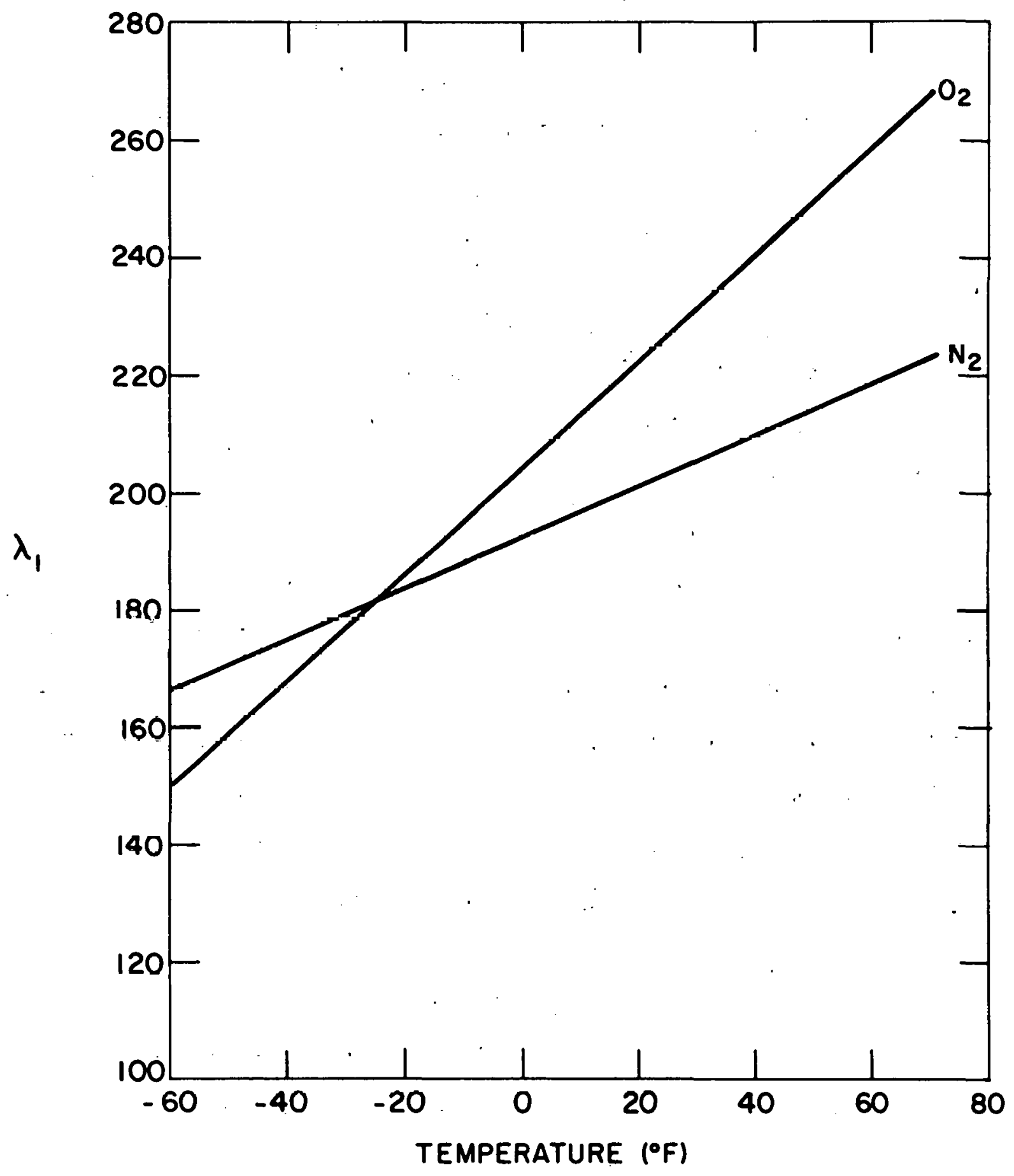

Fig. 1. Values of $\lambda_{1}$ for $0_{2}$ and $N_{2}$. 


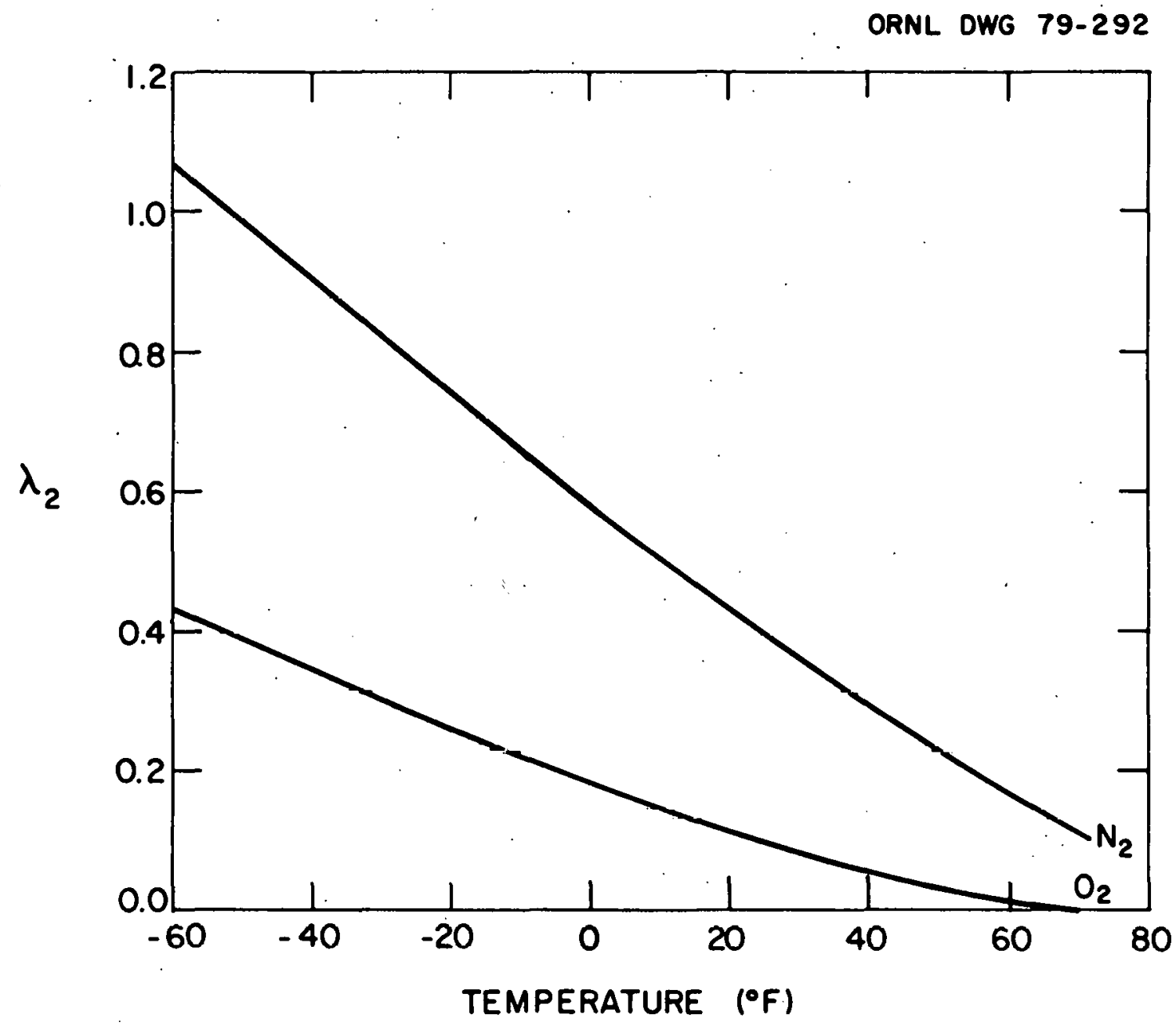

Fig. 2. Values of $\lambda_{2}$ for $\mathrm{O}_{2}$ and $\mathrm{N}_{2}$. 


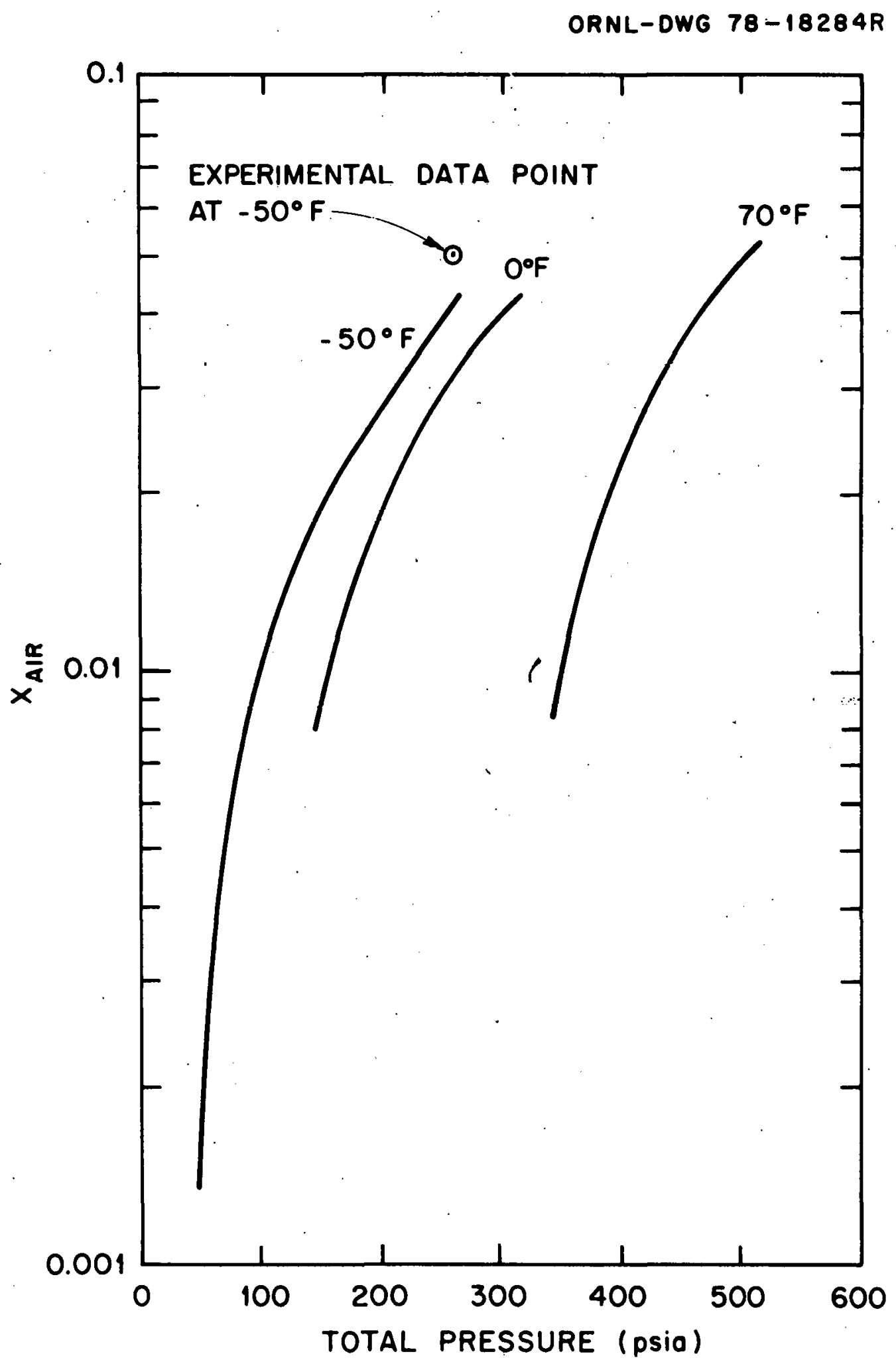

Fig. 3. Mole fraction solubility of air in $\mathrm{SF}_{6}$. 


\section{AIR SOLUBILITY MEASUREMENT}

The solubility of air in liquid $\mathrm{SF}_{6}$ was measured to check the calculated solubilities. The apparatus used is shown in Fig. 4. The system between valves $B$ and $E$ and the sample cylinder were evacuated using a cryogenic molecular sieve pump (Varian VacSorb) to a pressure of less than $50 \mu$. The volume between valves $A$ and $B$, containing air at ambient pressure $(746 \mathrm{~mm} \mathrm{Hg})$, was connected to a cylinder of $\mathrm{SF}_{6}$ at ambient temperature and cooled in a dry ice--chloroform bath. In this way, the A-B volume was pressurized to the vapor pressure of $\mathrm{SF}_{6}(257 \mathrm{psig})$ and filled with a mixture of liquid $S_{6}$ and air. Valve $B$ was then opened slowly and the $\mathrm{SF}_{6}$ liquid was allowed to flow into the volume tubing between valves $B$ and $C$, thus yielding a liquid at $-50^{\circ} \mathrm{F}$ which had been equilibrated with air at a partial pressure of $0.974 \mathrm{~atm}$.

The B-C tube was allowed to warm to ambient temperature to vaporize the liquid, and the gas was then transferred to the sample cylinder. Analysis by mass spectrometer yielded the following results:

\section{mass \%}

$\begin{array}{lr}\mathrm{H}_{2} \mathrm{O} & 0.05 \\ \mathrm{~N}_{2}+\mathrm{CO} & 0.86 \\ \mathrm{O}_{2} & 0.17 \\ \mathrm{Ar} & 0.01 \\ \mathrm{SF}_{6} & \frac{98.92}{100.01}\end{array}$


ORNL DWG 79-294R

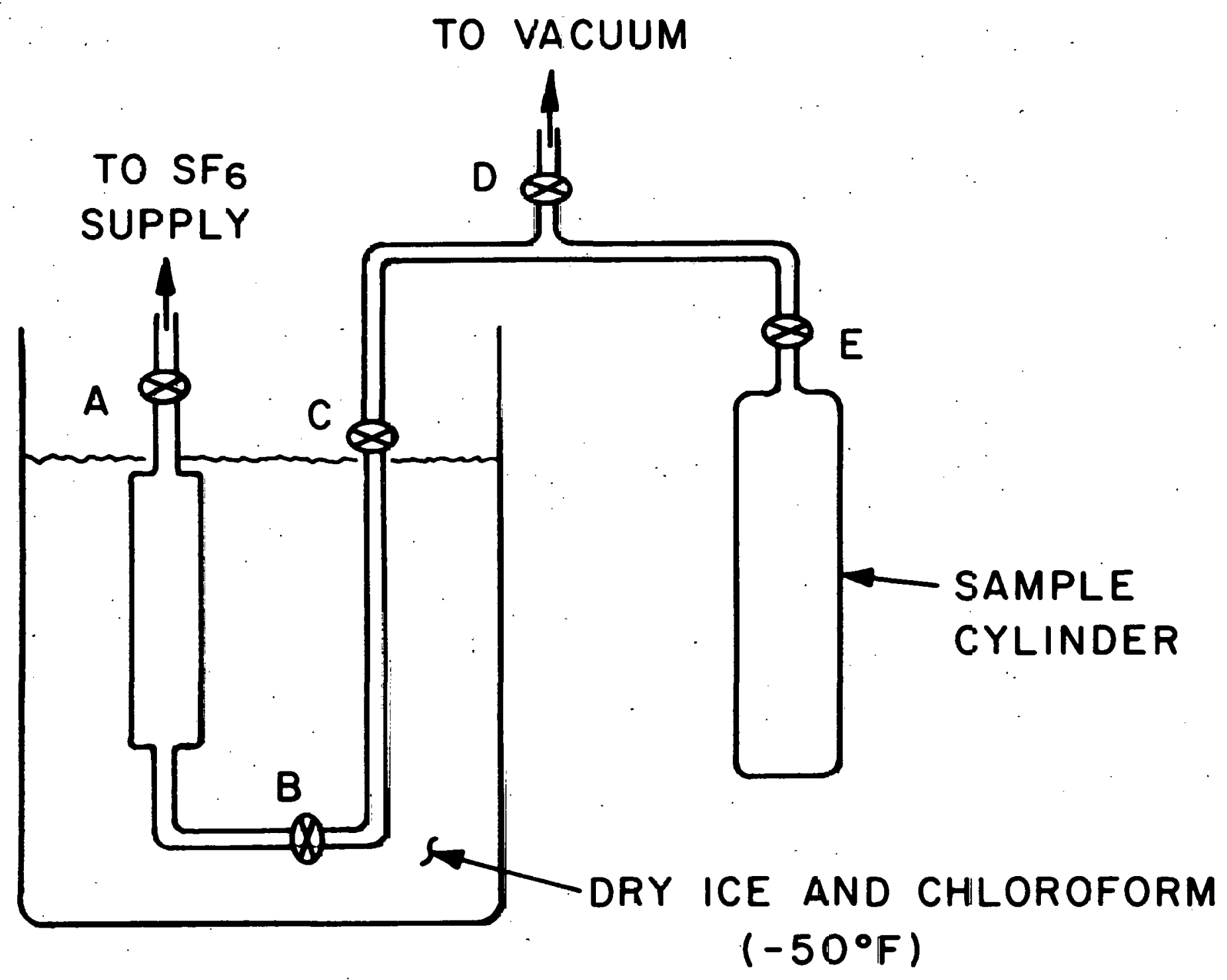

Fig. 4. Air-SF 6 solubility apparatus. 
The solubilities are $0.043 \mathrm{~m} . \mathrm{f}$. for $\mathrm{N}_{2}$ (assuming no carbon monoxide is present) and 0.007 m.f. for $0_{2}$, giving a total solubility of 0.050 for air. From regular solution theory, the calculated values are 0.023 for $\mathrm{N}_{2}$ and 0.018 for $\mathrm{O}_{2}$, giving a total air solubility of 0.041 . These. values are shown in Fig. 3.

\section{PURIFICATION METHODS}

\subsection{Liquefaction}

One of the simplest operations that can be performed with the contaminated gas is to cool it and produce a liquid phase. Two questions naturally arise: (1) how much of the $\mathrm{SF}_{6}$ can be recovered by liquefaction; and (2) how pure will the liquid be? The distribution of gases and liquids obtained from an initial gas mixture can be estimated by the application of Dalton's and Raoult's laws:

$$
y_{S F_{6}} P_{T}=X_{S F_{6}} P_{V} \text {, }
$$

where

$$
\begin{aligned}
\mathrm{y}_{S_{6}} & =\text { mole fraction of } \mathrm{SF}_{6} \text { in vapor, } \\
\mathrm{P}_{\mathrm{T}} & =\text { total pressure, } \\
\mathrm{X}_{\mathrm{SF}_{6}} & =\text { mole fraction of } \mathrm{SF}_{6} \text { in liquid, and } \\
\mathrm{P}_{V} & =\text { vapor pressure of pure } \mathrm{SF}_{6} .
\end{aligned}
$$

The conditions that result in air solubilities greater than 1 or $2 \%$ are not of interest; therefore, we can take $\mathrm{X}_{\mathrm{SF}_{6}} \cong 1$ with the understanding that results are not accurate where this assumption does not hold. To a 
good approximation, the composition of the vapor phase is thus fixed when the total pressure and temperature are specified.

Essentially all of the 207 moles of air remain in the vapor phase; the amount of $\mathrm{SF}_{6}$ liquefied at a given total pressure and temperature can be calculated by obtaining the composition of the vapor phase from Eq. (2). The amount of $\mathrm{SF}_{6}$ that is condensed is the difference between the original 1200 moles and the amount in the vapor. Figure 5 is based on this procedure and shows that over $95 \%$ of the $\mathrm{SF}_{6}$ in Case 1 can be liquefied at moderate pressures if the mixture is cooled to $0^{\circ} \mathrm{F}$ or below. The solubility estimates in Fig. 3, however, indicate that the amount which can be liquefied is less than $90 \%$ at temperatures to $-50^{\circ} \mathrm{F}$ if the liquid phase composition is to be limited to $1 \%$ air. A purification flowsheet for Case 1 utilizing liquefaction is given in Fig. 6, which is based on a 20-day cleanup period for this worst-case incident. After liquefaction, a vapor phase remains which is $40 \% \mathrm{SF}_{6}$ and amounts to $1050 \mathrm{lb} /$ day of $\mathrm{SF}_{6}$. This stream requires further purification by some operation labeled "separator" in Fig. 6.

For Case 2, starting with a vapor containing $1 \%$ air, liquefaction is more efficient for the purification of $\mathrm{SF}_{6} . A t-50^{\circ} \mathrm{F}$ and a total pressure of 50 psia, over $96 \%$ of the $\mathrm{SF}_{6}$ is liquefied and, as shown in Fig. 3, the composition of the liquid phase is only $0.0018-m . f$. air.

\subsection{Molecular Sieves}

Molecular sieves with very uniform pore sizes are available commercially with pores too small for the $\mathrm{SF}_{6}$ molecule to enter. A separation process can be devised in which the mixture of air and $\mathrm{SF}_{6}$ passes through 


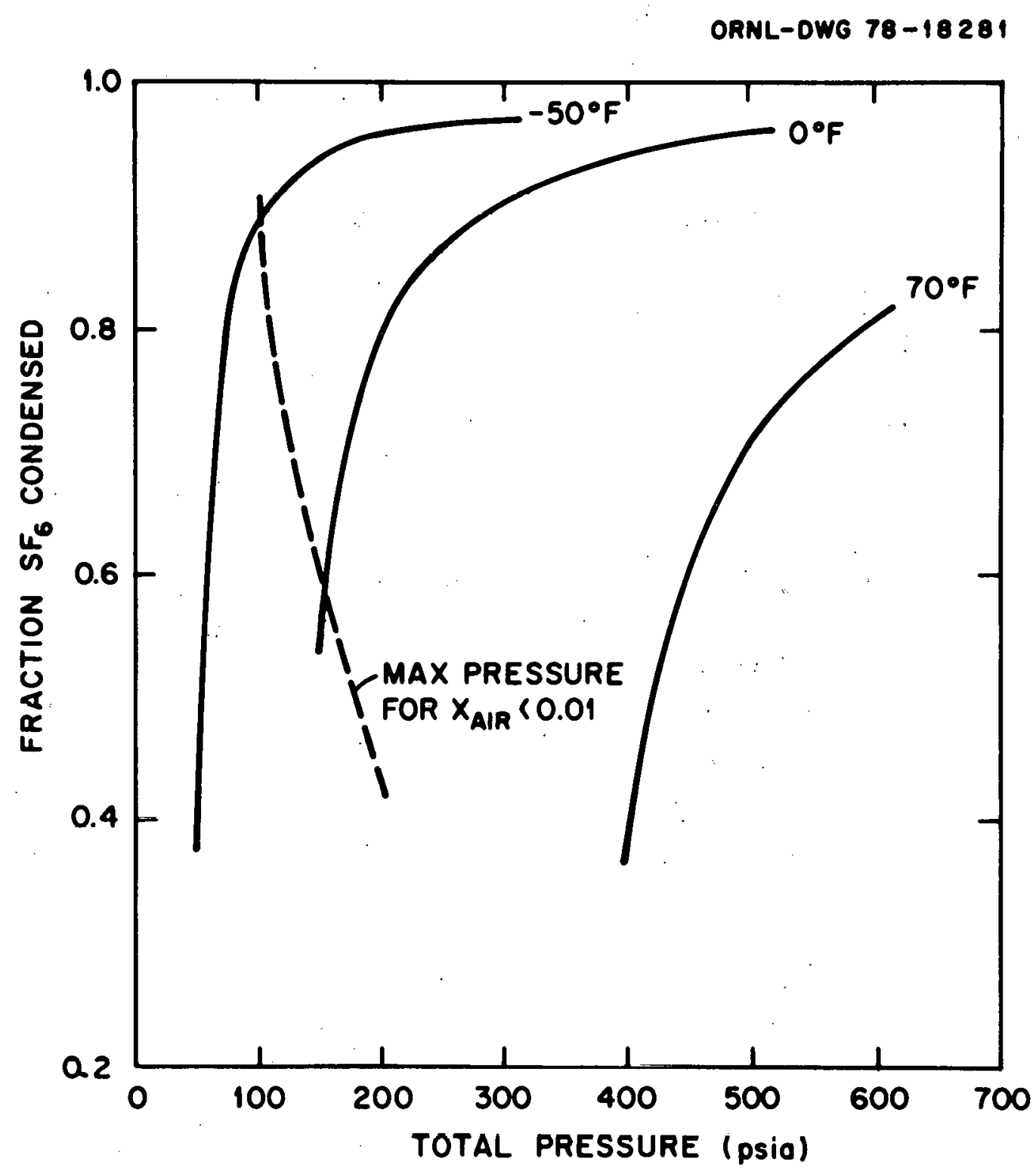

Fig. 5. Fraction of $\mathrm{SF}_{6}$ condensed starting with $\mathrm{Y}_{\mathrm{a} i \mathrm{r}}=0.15$. 
ORNL-DWG 78-18285R

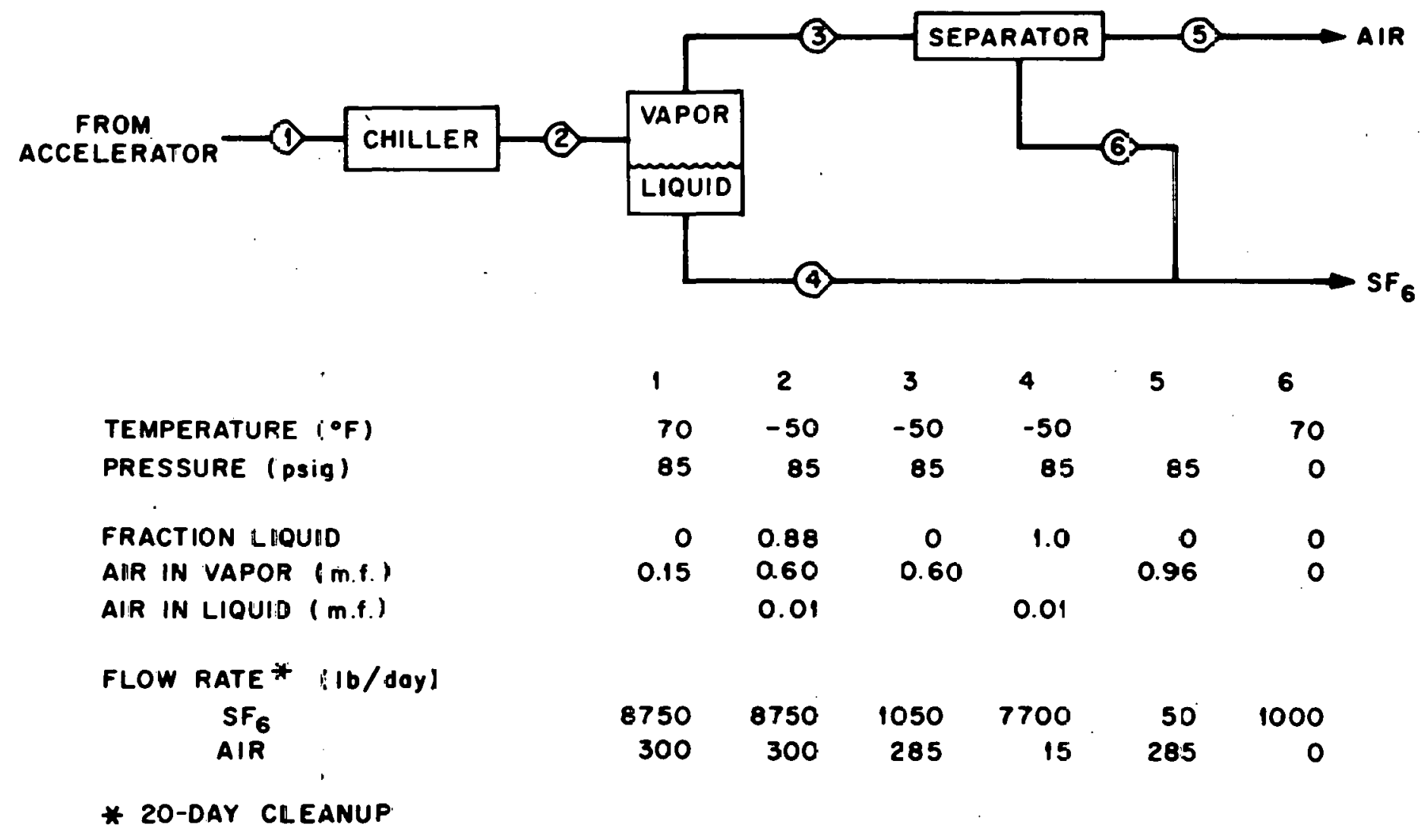

Fig. 6. Flowsheet for Case 1. 
a bed of molecular sieve, and the air is trapped out while the $\mathrm{SF}_{6}$ passes through. If the "separator" in Fig. 6 is assumed to be a bed of molecular sieve, it can be seen that as the gas stream passes through the bed and .loses air, it becomes saturated and liquefies., The liquid might cause problems by blinding the pore openings, preventing the gaseous air from entering. After the bed is saturated with air, it would be taken off stream, depressurized, and warmed to release the air in preparation for another cycle.

The required size of a bed of molecular sieves for this application was discussed with engineers at Linde (Division of Union Carbide, Cleveland, Ohio). The bed cannot be operated below approximately $-50^{\circ} \mathrm{F}$ because the $\mathrm{SF}_{6}$ would freeze and plug the bed. Equilibrium loadings for specially dehydrated (activated) molecular sieves at $-50^{\circ} \mathrm{F}$ are $2.5 \mathrm{lb}$ of, oxygen and $6 \mathrm{lb}$ of nitrogen per $100 \mathrm{lb}$ of molecular sieves. Practical design values recommended by Linde are 1 ib of oxygen and $4 \mathrm{lb}$ of nitrogen per 100 1b of molecular sieves. For the condition presented in Fig. 6, a minimum bed size of 15,000 lb is required. Molecular sieves, which are ceramic oxides, are very poor conductors of heat, and temperature cycling of such a large bed would require prohibitively long periods of time. Therefore, the use of molecular sieves does not appear to be a good solution to the problem.

\subsection{Desublimation}

Freezing out $\mathrm{SF}_{6}$ from a mixture with air has been practiced on small batches of gas such as at Chalk River. The feasibility of desublimation on a large, continuous scale was investigated for the present application. Desubliming is not a widely practiced operation, and the engineering of 
desublimers is not well established in comparison with most other unit operations. However, a great deal of the existing expertise at ORNL is the result of routine desublimation of $\mathrm{UF}_{6}$. A design procedure that includes a computer program ${ }^{7}$ was applied to the desublimation of krypton. ${ }^{8}$ Hence the design procedure that is available has been tested on two different chemical systems and has been verified experimentally on both of them.

The desublimer would be the separator in Fig. 6. To recover $90 \%$ of the $\mathrm{SF}_{6}$ entering the desublimer ( $99 \%$ of the $\mathrm{SF}_{6}$ leaving the accelerator), the partial pressure must be reduced to $4 \mathrm{psia}$, which requires a temperature of $-115^{\circ} \mathrm{F}$. Allowing for heat transfer resistance, a cooling fluid temperature of $-130^{\circ} \mathrm{F}$ or below is needed.

The desublimer can have many geometrical configurations, but one of the simplest and most effective is the finned tube (Fig. 7). As the superheated gas flows through the tube, the gas near the cold surface is cooled to the point where the partial pressure of $S_{6} F_{6}$ exceeds the vapor pressure and solids are deposited on the cold surfaces. The loss of $\mathrm{SF}_{6}$ from the gas near the surfaces gives rise to a transverse mass transfer driving force, and the rate of mass transfer becomes one of the most important rate phenomena occurring in the desublimer. At the same time, the bulk gas is cooled as it flows along the tube and may generate $\mathrm{SF}_{6}$ "snow" when it becomes subcooled. Both phenomena must be considered in the design. The greatest unknowns in the calculations lie in the values of density and thermal conductivity of the deposited solids.

The design program ${ }^{7}$ assumes that the snow is deposited at the same axial position at which it is formed. High gas velocities cause the 


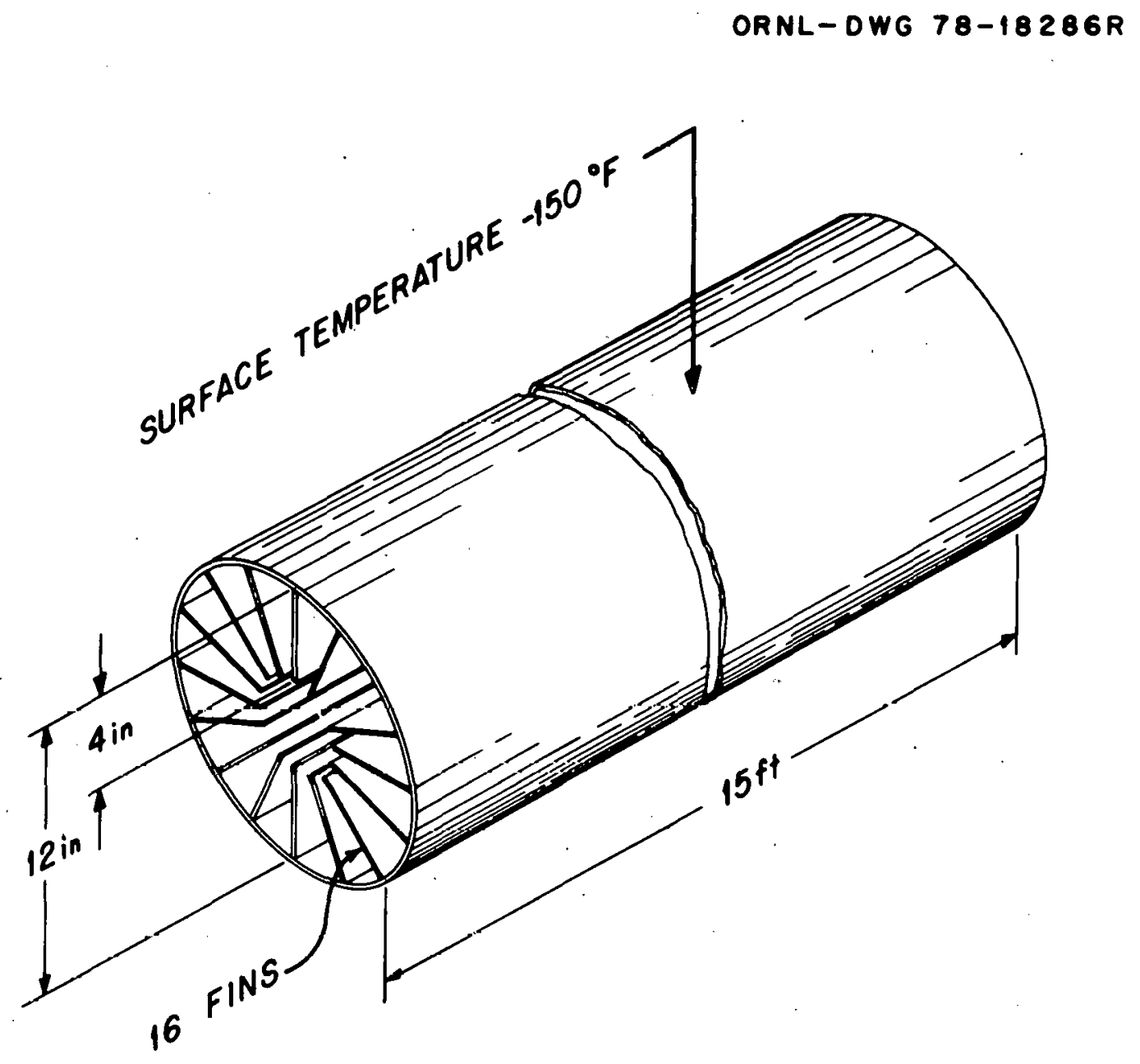

Fig. 7. Finned-tube desublimer. 
snow to be carried further along the tube. Desublimers of $\mathrm{UF}_{6}$ are fitted with filters at the gas outlets to prevent loss of snow. A rule of thumb derived from UF 6 . experience is that the accumulation of snow on the filter is small if the superficial gas velocity is kept below $0.5 \mathrm{ft} / \mathrm{sec}$. In one run made with a gas velocity that was about twice this value, there was no significant snow accumulation at the gas outlet. ${ }^{8}$

Guidelines for estimating the density of the deposited solids are very rough. A frost-to-liquid density ratio of 0.69 has been reported. ${ }^{7}$ This does not agree with the generally accepted meteorological ratio of $10 \mathrm{in.}$ of snow per $1 \mathrm{in}$. of rain. A ratio of 0.5 was assumed for krypton, but it was not directly confirmed by experiments. ${ }^{8}$ If we assume a ratio of 0.5 for $\mathrm{SF}_{6}$, we obtain a solids density of $57 \mathrm{1b} / \mathrm{ft}^{3}$.

The volume of a 12-in.-diam by 15-ft-long desublimer is about 12 $\mathrm{ft}^{3}$. If the solids density is assumed to be $57 \mathrm{lb} / \mathrm{ft}^{3}$, such a desublimer would hold at maximum $670 \mathrm{lb}$ of $\mathrm{SF}_{6}$ solid. Since a desublimer cannot be filled completely, let us assume that a desublimer of this size could be loaded with $525 \mathrm{lb}$ of $\mathrm{SF}_{6}$. If this is compared with stream 3 in Fig. 6, we find that two cycles of loading per day would handle the flow.

The operation of a 12-in.-diam desublimer that is $15 \mathrm{ft}$ long and has 16 radial fins was investigated for a coolant fluid temperature of $-150^{\circ} \mathrm{F}$. The heat transfer coeffictent $(h)$ between the gas and the wal1 was calculated with the following equation: ${ }^{9}$

$$
\frac{h}{L G}=0.67\left(\frac{L G}{\mu}\right)^{-1 / 2} \operatorname{Pr}^{-2 / 3}
$$


where $L$ is the axial length of the fin. High coefficients can be obtained with small values of $L$, which keep the boundary layer from becoming well developed. Even though our exchanger was $15 \mathrm{ft}$ 1ong, $L$ could be made small by specifying that the fins were cut and rotated every 6 in. or foot of length.

The results of the computer study show that the desublimer would reach a loading of $525 \mathrm{lb}$ in about $2.5 \mathrm{hr}$. The gas velocity would remain well below the $0.5-\mathrm{ft} / \mathrm{sec}$ limit. The effluent gas composition (m.f. of $\mathrm{SF}_{6}$ ) during the loading period ranged from 0.007 after $15 \mathrm{~min}$ to 0.048 after $2.5 \mathrm{hr}$ and resulted in an $\mathrm{SF}_{6}$ recovery for the desublimer in excess of $90 \%$. Solids deposition profiles during the $2.5-\mathrm{hr}$ period are plotted in Fig. 8. Our calculations indicate that this is a workable design.

Because the thermal conductivity and density of the deposited solids are only estimates, the sensitivity of the design to these variables was investigated. A thermal conductivity of $0.1 \mathrm{Btu} / \mathrm{hr} \cdot \mathrm{ft} \cdot{ }^{\circ} \mathrm{F}$ was used in the previous calculations, which is the same value that seems to work for $\mathrm{UF}_{6}$ desublimers. Computer runs were made in which the thermal conductivity was decreased by a factor of 10 to $0.01 \mathrm{Btu} / \mathrm{hr} . \mathrm{ft} .{ }^{\circ} \mathrm{F}$ and in which the density of the deposited solids was decreased by a factor of 2 to $30 \mathrm{lb} /$ $\mathrm{ft}^{3}$. The effects of these changes were similar. The design as it stands would not work because the effluent gas concentration of $\mathrm{SF}_{6}$ would become excessive after about $1.5 \mathrm{hr}$. The hardware could be made to work by using three cycles per day, collecting 350 1b/cycle in about $1.5 \mathrm{hr}$. If the low values of both density and thermal conductivity are applied at the same time, a larger desublimer would be required.

Based on the design calculations, the use of a desublimer appears feasible for the purification of $\mathrm{SF}_{6}$. However, the uncertainties of 


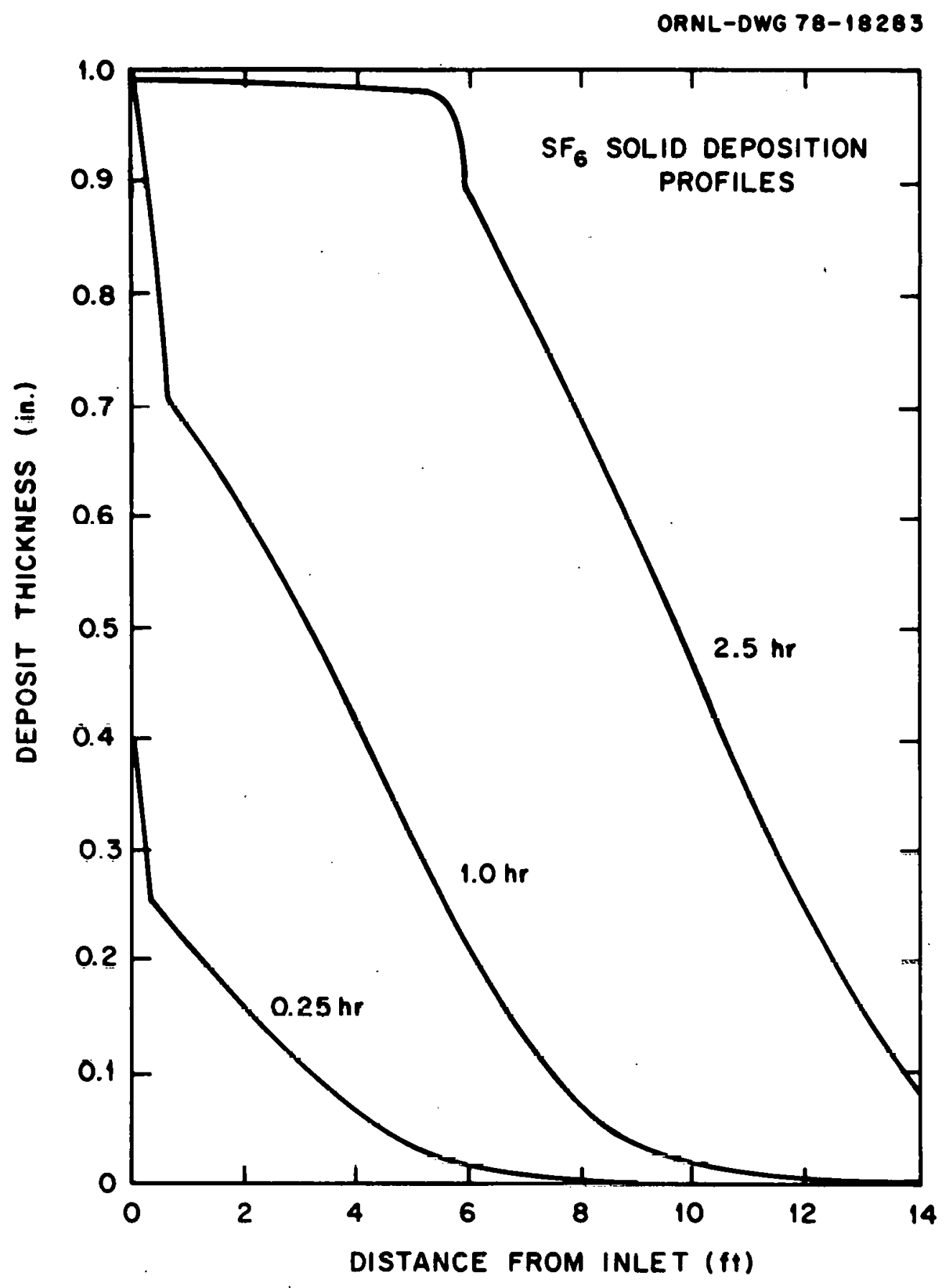

Fig. 8. Solid deposition profiles of $\mathrm{SF}_{6}$. 
solids properties would require that a small-scale desublimer be built and tested against design calculations before design of a full-scale desublimer could proceed.

\subsection{Adsorption onto Activated Carbon}

The affinity of $\mathrm{SF}_{6}$ for activated carbon has already been noted. A conventional process arrangement would be to pass the $\mathrm{SF}_{6}$-air mixture through the bed and allow the $\mathrm{SF}_{6}$ to be adsorbed and the air to flow through. When the bed is saturated and $\mathrm{SF}_{6}$ begins to break through, the bed would be taken off stream and warmed to release the $\mathrm{SF}_{6}$. No data on equilibrium loadings of $\mathrm{SF}_{6}$ onto activated carbon were available in a literature search.

A simple apparatus was assembled to measure the adsorption capacity of activated carbon for $\mathrm{SF}_{6}$ (Fig. 9). Dry air and $\mathrm{SF}_{6}$ gases were metered into a cooling coil and passed into a column packed with activated charcoal. The 2-in.-diam by $2-\mathrm{ft}-$ long column contained $430 \mathrm{~g}$ of activated charcoal. The gases and column were cooled and maintained at -50 to $-100^{\circ} \mathrm{F}$ before the start of a run. The effluent gases from the column passed through a gas density analyzer (manufactured by GOW-MAC), which provided a continuous analysis of the gas composition.

Ten runs were made with gas phase compositions that ranged from 0.068- to 0.58-m.f. $\mathrm{SF}_{6}$ (Table 2). Breakthrough curves were very sharp for all cases; essentially no $\mathrm{SF}_{6}$ was in the effluent gas for the first $30 \mathrm{~min}$, after which the effluent composition suddenly rose from 0 to $100 \% \mathrm{SF}_{6}$ within 1 to 2 min. A sample curve is shown in Fig. 10. This behavior is very desirable in an adsorption system and would permit high utilization of the bed. Bed loadings are also encouragingly high, 
ORNL-OWG 78-18287R

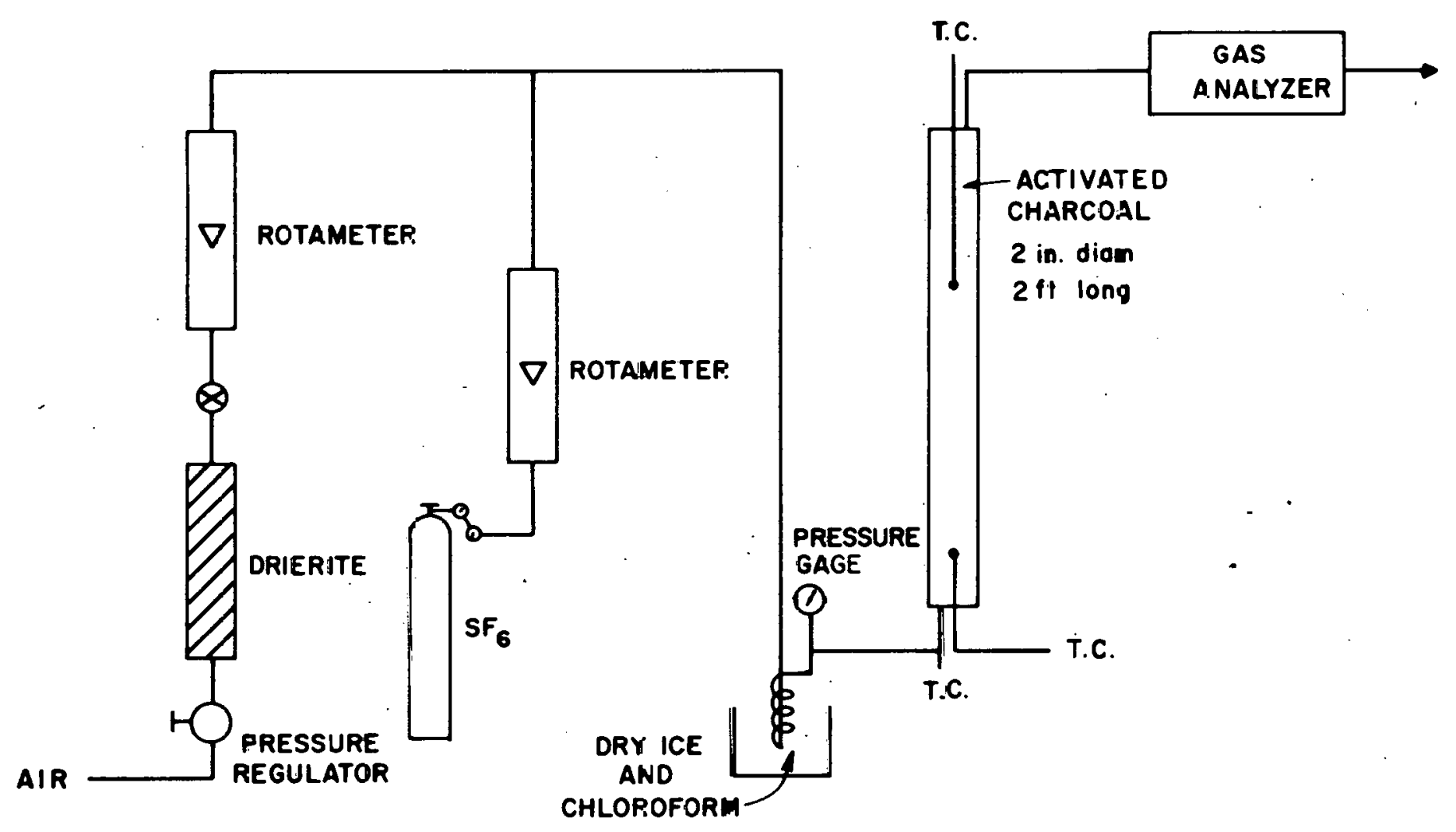

Fig. 9. Apparatus for activazed carbon adsorption of $\mathrm{SF}_{6}$. 
Table 2. Adsorption of $\mathrm{SF}_{6}$ onto activated carbon

\begin{tabular}{|c|c|c|c|c|c|c|}
\hline Run & $\begin{array}{c}\text { Feed } \\
\text { composition } \\
\text { (m.f., SF })\end{array}$ & $\begin{array}{c}\text { Inlet } \\
\text { pressure } \\
\text { (psia) }\end{array}$ & $\begin{array}{c}\text { Inlet } \\
\text { temperature } \\
\left({ }^{\circ} \mathrm{F}\right)\end{array}$ & $\begin{array}{c}\text { Time to } \\
\text { breakthrough } \\
(\min )\end{array}$ & $\begin{array}{c}\text { Partial } \\
\text { pressure } \\
\text { SF }_{6}\end{array}$ & $\begin{array}{l}\text { Loading } \\
\left(\mathrm{g} \mathrm{SF}_{6} / \mathrm{g} \mathrm{C}\right)\end{array}$ \\
\hline 2 & 0.251 & 28.4 & -63 & 31.5 & 7.14 & 1.48 \\
\hline 3 & 0.336 & 21.7 & -63 & 34.8 & 7.29 & 1.43 \\
\hline 4 & 0.423 & 20.7 & -62 & 30.0 & 8.77 & 1.20 \\
\hline 5 & 0.780 & 17.7 & -62 & 36.5 & 10.27 & 1.32 \\
\hline 6 & 0.370 & 28.7 & -51 & 25.8 & 10.80 & 1.03 \\
\hline 7 & 0.205 & $24 . ?$ & -76 & 29.4 & 4.97 & 1.09 \\
\hline 8 & 0.165 & 20.7 & -65 & 50.3 & 3.41 & 1.32 \\
\hline 9 & 0.118 & 22.7 & -73 & 57.1 & 2.69 & 1.07 \\
\hline 10 & 0.068 & 27.2 & -55 & 113.3 & 1.86 & 1.12 \\
\hline
\end{tabular}




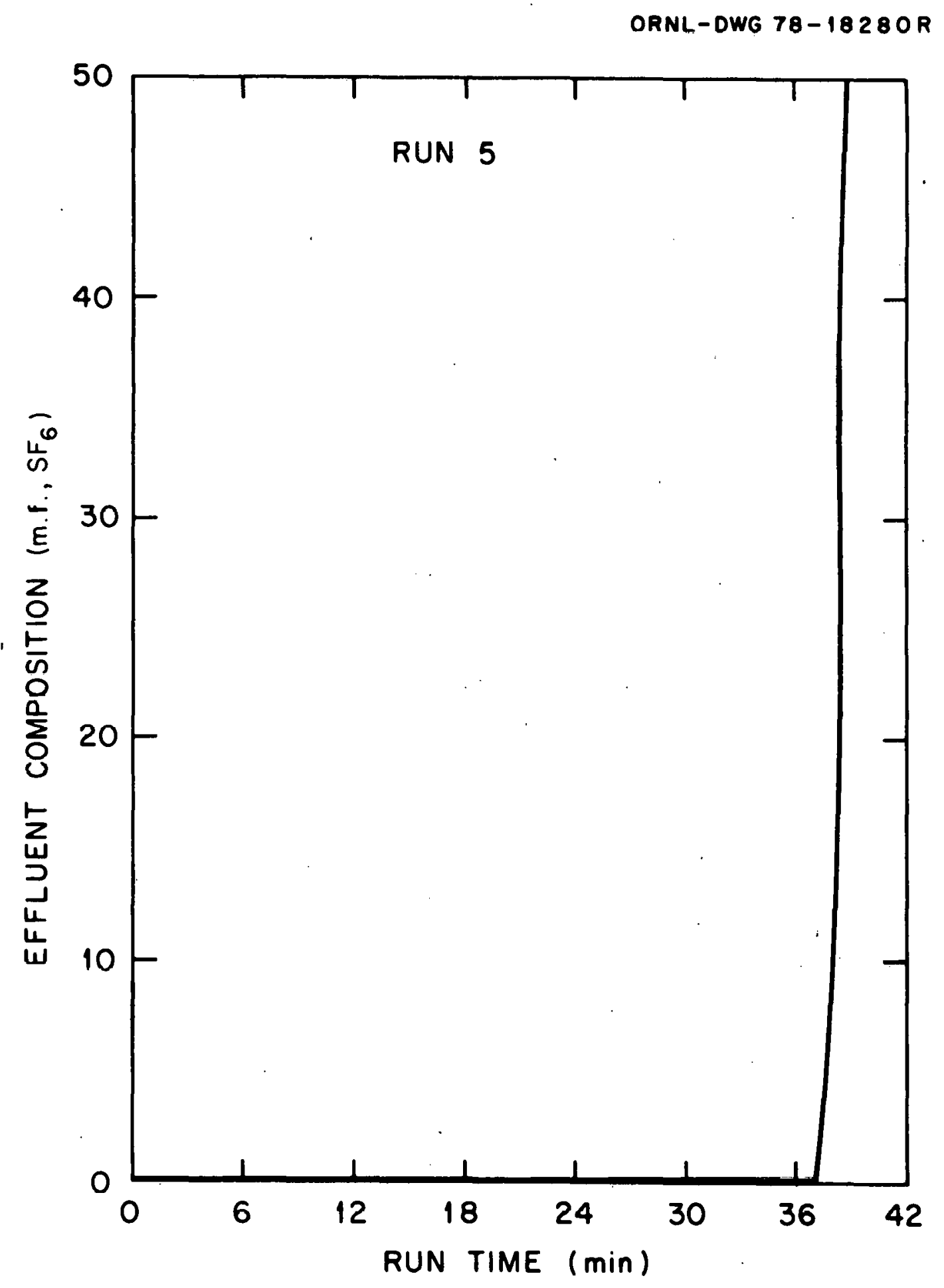

Fig. 10. Breakthrough curve for Run 5. 
ranging from 1.0 to $1.48 \mathrm{~g}$ of $\mathrm{SF}_{6}$ absorbed per $\mathrm{g}$ of carbon for all runs.

A large heat-of-adsorption effect was noted. As shown in Fig. 11, the temperature near the center of the bed suddenly rose above $0^{\circ} \mathrm{F}$ as the mass transfer zone reached that part of the bed, then slowly fell to almost that of the inlet temperature at breakthrough. Thus the loadings cannot be taken as isothermal data.

The loading data in Table 2 do not correlate with partial pressures of $\mathrm{SF}_{6}$, as might be expected. The loadings are so high that most of the void volume of the charcoal bed is filled with $\mathrm{SF}_{6}$ in these runs, and thus the expected correlation was not obtained.

Favorable results have been obtained in preliminary feasibility calculations for a purification system that uses charcoal adsorption for the separation (see Fig. 6). The separator could consist of two charcoal beds, one of which is on stream and loading for $12 \mathrm{hr}$, while $\mathrm{SF}_{6}$ is recovered from the other by a temperature cycle. Each bed requires a capacity of $525 \mathrm{lb}$ of $\mathrm{SF}_{6}$, which means the bed must contain $525 \mathrm{lb}$ of activated charcoal for a loading ratio of 1.0. Using a charcoal density of $35 \mathrm{lb} / \mathrm{ft}^{3}$, each bed would have a volume of only $15 \mathrm{ft}^{3}$. These volumes are very reasonable.

A refrigeration system to cool $8750 \mathrm{lb}$ of $\mathrm{SF}_{6}$ per day and $300 \mathrm{lb}$ of air per day to $-50^{\circ} \mathrm{F}$ is also reasonable. The enthalpy of $\mathrm{SF}_{6}$ gas at $70^{\circ} \mathrm{F}$ is $53 \mathrm{Btu} / \mathrm{lb} ; \mathrm{SF}_{6}$ gas at $-50^{\circ} \mathrm{F}$ is $43 \mathrm{Btu} / \mathrm{lb}$, and $\mathrm{SF}_{6}$ liquid at $-50^{\circ} \mathrm{F}$ is $-2 \mathrm{Btu} / \mathrm{lb}$ (based on saturated liquid at $-40^{\circ} \mathrm{F}$ ). The total refrigeration requirements are less than 20,000 Btu/hr for cooling and liquefying gases. Cooling requirements for temperature cycling 
ORNL DWG 78-18282

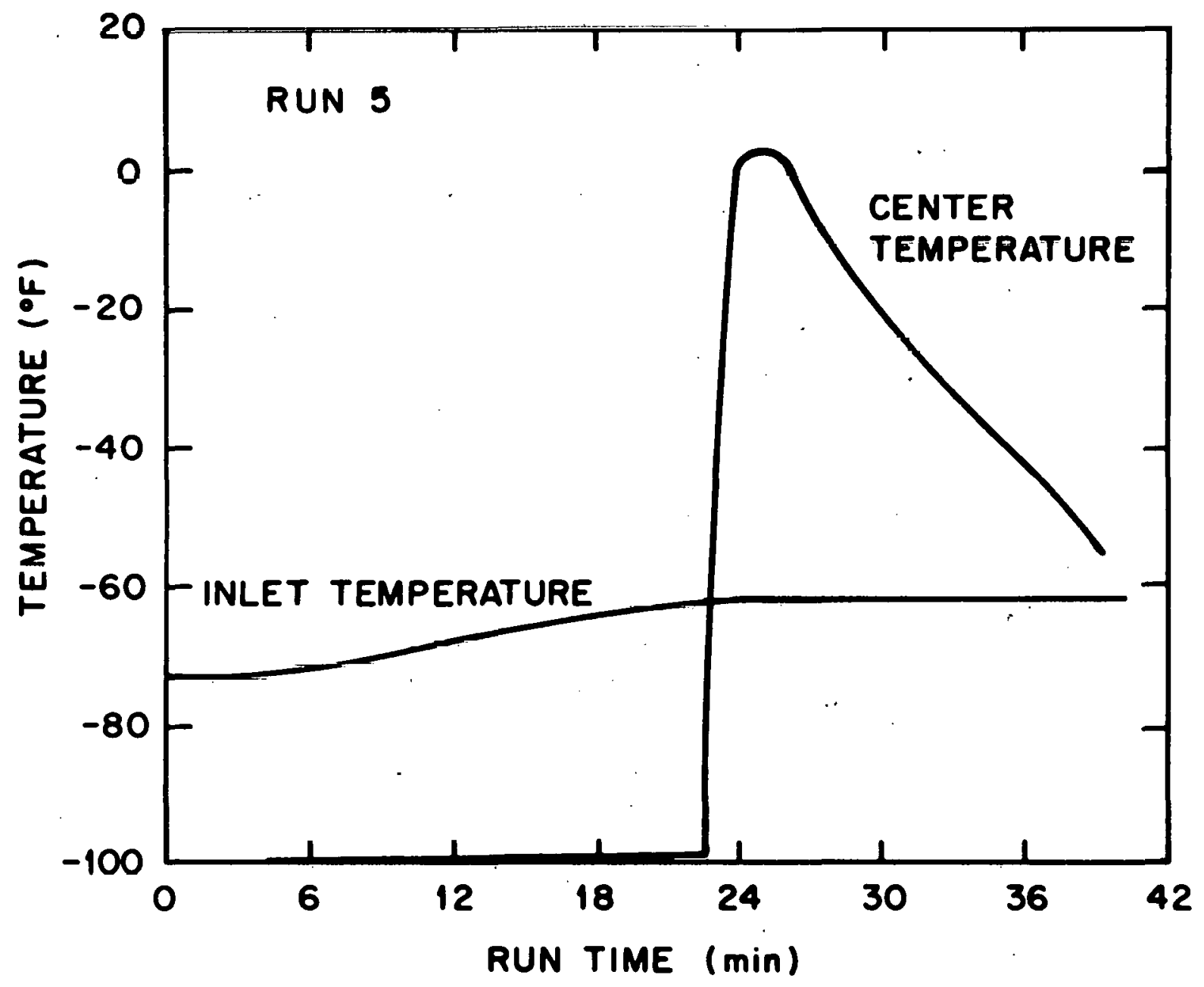

Fig. 11. Charcoal-bed temperatures for Run 5; breakthrough at $37 \mathrm{~min}$. 
the carbon bed would be only about $20 \%$ of this. Thus, 2 tons of refrigeration should be adequate. A rough estimate of the cost of such a system indicates a cost of about $\$ 15,000$.

\section{ACKNOWLEDGMENTS}

The contributions of R. R. Brunson, S. D. Clinton, and R. E. Barker to the experimental work are gratefully acknowledged. The careful review of the manuscript by Charles Jones was very helpfur.

\section{REFERENCES}

1. C. M. Jones, Revue Phys. App1. 12, 1353 (1977).

2. P. Hurley and N. Burn in Proceedings of the Symposium of North East Accelerator Personnel (S.N.E.A.P.), Florida State University, Tallahassee (1974).

3. C. Brassard, p. 60 in Proceedings of the Symposium of North East Accelerator Personnel (S.N.E.A.P.), Florida State University, Tallahassee (1976).

4. L. Rowton, p. 67 in Proceedings of the Symposium of North East Accelerator Personnel (S.N.E.A.P.), Florida State University, Tallahassee (1976).

5. W. T. Milner, Sulfur Hexafluoride Transfer and Storage System of the Hol ifield Heavy Ion Research Facility: Some Thermodynamic Properties, ORNL/TM-6249 (February 1978).

6. J. H. Hildebrand, J. M. Prausnitz, and R. L. Scott, Regular and Related Solutions, Van Nostrand Reinhold, New York, 1970.

7. D. I. Dunthorn, The Design of Batch Desublimers, K-L-6220 (September 1968).

8. R. S. Eby, The Desublimation of Krypton from a Noncondensable Carrier Gas, K-1896 (August 1978).

9. W. H. McAdams, Chem. Eng. Prog. 46, 125 (1950). 
THIS PAGE

WAS INTENTIONALLY

LEFT BLANK 
ORNL/TM-6939

\section{INTERNAL DISTRIBUTION}

\section{1-2. Central Research Library}

3. Document Reference Section

4-8. Laboratory Records

9. Laboratory Records - RC

10. MIT Practice School

11. ORNL Patent Section

12. R. E. Barker

13. J. M. Begovich

14. J. A. Benjamin

15. L. G. Christophorou

16. S. D. Clinton

17. P. W. Fisher

18. R. W. Glass

19. J. R. Hightower

20. V. A. Jacobs

21-23. C. M. Jones

24. R. E. Leuze

25-29. J. J. Perona

30. W. W. Pitt

31. C. D. Scott

32-33. J. S. Watson

34. A. Zucker

35. L. J. Colby, Jr. (consultant)

\section{EXTERNAL DISTRIBUTION}

36. W. J. Haubach, Office of Basic Energy Sciences, DOE, Mai1 Station J-309, GTN, Washington, D.C. 20545

37. E. S. Pierce, Office of Basic Energy Sciences, DOE, Mai1 Station J-309, GTN, Washington, D.C. 20545

38. Selim M. Senkan, Department of Chemical Engineering, Massachusetts Institute of Technology, Room 66-501, Cambridge, Mass. 02139

39. F. Dee Stevenson, Office of Basic Energy Sciences, DOE, Ma il Station J-309, GTN, Washington, D.C. 20545

40. Office of Assistant Manager, Energy Research and Development, DOE-ORO, Oak Ridge, Tenn. 37830

47-67. Technical Information Center, Oak Ridge, Tenn. 37830 